\title{
SUBSTITUTION OF HIJAAN WITH WASTE MEDIUM MEDIA FERMENTATION WHITE FERMENTATION WITH NON KARKAS PERCENTAGE IN LOCAL SHEEP
}

\author{
Iin Dwi Lestari Silitonga, Hasnudi, Hamdan, T H Wahyuni, E R Mirwandhono \\ Animal Production Program Study, Faculty of Agriculture, University of North \\ Sumatera, Medan 20155, Indonesia \\ E-mail: iinmonjo4@gmail.com
}

\begin{abstract}
This study aims to determine whether the waste media plant white fermented oyster mushroom can substitute forage on sheep against non-carcass components are feasible eaten. This research was conducted in Namo Trasi Village, Pasar VIII, in October - December 2017 by using local sheep with average weight of $9 \pm 0.25 \mathrm{~kg}$. The research design used in this study was a complete randomized design (RAL) with 4 treatments and 5 replicates, consisting of P0 (60\% non-wasted greenhouse vegetation fermentation $+40 \%$ concentrate), P1 (45\% forage and waste) medium planting white oyster mushroom fermentation $15 \%+$ concentrate $40 \%$ ), P2 (forage $30 \%$ and waste medium planting white oyster mushroom fermentation 30\% + concentrate 40\%) and P3 (forage 15\% and sewage media plant white fermented oyster mushrooms $45 \%+40 \%$ concentrate). The parameters observed were weight percentage of head, leg, skin, tail, trachea and lungs, liver, heart, blood, and gastrointestinal tract.

The result of the research shows that the waste of fermented white oyster mushroom media can substitute forage as local sheep feed, but it can not increase the percentage of non-carcass component that is feasible to eat.
\end{abstract}

\section{Introduction}

The need for animal protein in Indonesia continues to increase in number so that the need for adequate animal protein supply for the community. Management improvement in livestock raising is one way to increase meat production. Goats are strategic commodities as an integral part of other farming enterprises and as contributors to national meat procurement.

A problem in developing countries especially in Indonesia is the low livestock productivity due to low quality feed associated with the availability of forage sources, especially during the dry season, so the need for alternative alternative forage is cheap, easy to obtain and available throughout the season. This makes breeders look for other alternatives that can be used as forage replacement forage materials.

Setiadi [1] feed is a material of animal feed in the form of dry and water. This feed material should be given to livestock as a basic necessity of life and production.

Food substances that need cattle in the feed can be separated into major components such as energy, protein, minerals and vitamins. These substances derived from the food consumed Haryanto [2].

Mushroom cultivation is an agricultural business that has recently developed very rapidly. White oyster mushroom is a type of fungus most favored by the people of Indonesia. Generally oyster mushrooms are consumed as vegetables with various preparations. The development of mushroom 
cultivation business increasingly rapidly and give impact on the amount of waste generated. Waste in question is a mushroom planting medium previously used as a medium of mushroom growth for approximately 4 months or 5-6 times the harvest.

Utilization of waste media planting mushrooms into raw material feed ruminants can be done by processing fermentation technology ransum. Fermentation is one solution to overcome the negative effects of waste media planting white oyster mushrooms and at once the solution to the lack of feed ruminants.

Thus, the availability of quantitative and qualitative feeds can be guaranteed throughout the year so that sheep production can be improved in line with the increasing demand for processed products from the livestock. In addition, the increasing knowledge of the community in processing various types of food including parts of non-carcass such as head, skin, liver, and digestive tract.

Waste media planting oyster mushroom formed by the material or media planting oyster mushrooms in the form of a mixture of sawdust with other materials not all used up when used to produce oyster mushrooms, but there are still remnants that are no longer effective to produce oyster mushrooms with good.

The waste of white oyster mushroom media has a high energy content and fiber fraction, which is $4260 \mathrm{kcal} / \mathrm{kg}$ of gross energy; 45.86\% TDN; 56.43\% Neutral Detergent Fiber (NDF); and 25.45\% Acid Detergent Fiber (ADF). However, the protein content is only $2.29 \%$ and crude $1.48 \%$ Tarmidi et all [3]

Efforts to improve the quality of nutrition, reduce, or eliminate the negative effects of certain feed ingredients can be done by using microorganisms through the fermentation process Winarno [4].

Non-carcass sections worthy of consumption such as blood, skin, head, tail and viscera (liver, heart, lungs and digestive tract) are also of high economic value, as they are the preferred food ingredients of the community. Some non carcass components that are not feasible to eat but processed with high technology can provide huge financial benefits Soeparno [5].

The purpose of this research is to know the percentage of non-carcass in local sheep given waste media planting white fermented oyster mushroom as alternative feed.

\section{Materials And Methods}

This research was conducted in Namo Trasi Village, Pasar VIII. The study lasted for three months starting from October 2017 to December 2017. Materials used in this study include local sheep as many as 20 tail with age 4-6 months and initial body weight $9 \pm 0.25 \mathrm{~kg}$. Rations consisting of forage, waste media planting fermented oyster mushroom with composition consisting of waste of dried or dried oyster mushrooms, fine probiotic Starbio, urea, molasses and water, and concentrate composed of fine bran, soybeans, coconut cake, molasses, ultra minerals and salts, Rhodallon and worm medicines.

The tool used is a cage of 20 units with a size of $1 \mathrm{mx} 0.5 \mathrm{~m}$, where to feed and drink as many as 20 units, white bucket size $15 \mathrm{~kg}$ as a place of fermentation, thermometer to know the temperature inside and outside the cage, cutting knife to slaughter sheep, $50 \mathrm{~kg}$ with a sensitivity of $2 \mathrm{~kg}$ to weigh the weight of sheep, the scales with a capacity of $2 \mathrm{~kg}$ with a sensitivity of 10 grams for weighing feed, cage cleaner.

The research method used a complete randomized design (RAL) with four treatments (P0, P1, P2, and P3). Each treatment was repeated three times. Each repetition consists of one goat, so the total number used is 20 sheep goats.

Treatment ration given in the form of four levels of balance of the use of media waste fermented oyster mushroom planting for 21 days as a substitute of grass in a complete feed is as follows:

P0: Green $60 \%$ + Concentrate $40 \%$

P1: Hijauan $45 \%$ + Waste medium oyster mushroom fermentation $15 \%$ + Concentrate $40 \%$

P2: Forage 30\% + Waste of white oyster mushroom media fermentation 30\% + Concentrate $40 \%$

P3: Green $15 \%$ + Waste of white oyster mushroom media fermentation $45 \%$ + Concentrate $40 \%$ 
The experimental mathematical model used is a complete randomized design (RAL) is:

$$
Y i j=\mu+\sigma i+C_{i j}
$$

Information:

Yij $=$ Response or observation value from the I-th treatment and the $\mathrm{j}$ th repeat

I $\quad=1,2,3 \ldots=$ treatment

$\mathrm{J} \quad=1,2,3 \ldots=$ repeat

$\mathrm{M} \quad=$ Common middle value

$\Sigma \mathrm{i} \quad=$ Effect of $\mathrm{i}$ th treatment

Eij $\quad=$ Effect error (Experimental Error)

\section{Non Carcass Preparation}

a. Mastery

Prior to the cutting, sheep first dipuasakan for 12 hours. This treatment aims to empty the stomach (intestine) so that the skin and muscles become weak because of increased glycogen content. In addition, this treatment will increase the proportion of meat to the weight of life.

b. Slaughter

Slaughter is done by cutting the neck right on the trachea, jugular vein, carotid artery and esophagus. After the slaughter is complete, sheep are hung with the hind legs above for smooth blood flow and for ease of difficulty.

c. Barking

The difficulties are carried out dry or without water, separating the head, the front legs and the corpus and tail joints at the base. Then slashed the skin on both hind legs in a circle wrist through the thighs and anus. The skin is peeled and slowly pulled down until the entire skin is released from the sheep.

d. Spend offal

Splitting offal by slashing the abdomen longitudinally from the point of the navel to the chest, then to the tail. After that remove the entire innards by hand and cut the back legs on the tarsus joints.

e. Weighing

Weighing is done after the non-carcass components are separated and then weighed.

Observed Variables

a. Percentage of head weight (\%)

The percentage of head weight obtained from the weight of the head divided by the empty body weight multiplied by $100 \%$

b. Foot weight prermentation (\%)

The percentage of leg weight obtained from the weight of the foot divided by the empty body weight multiplied by $100 \%$

c. Percentage of skin weights $(\%)$

Percentage of skin weights obtained from skin weight divided by empty body weight multiplied by $100 \%$

d. Percentage of tail weights $(\%)$ $100 \%$

Percentage of tail weight obtained from tail weight divided by empty body weight multiplied by

e. Percentage of tracheal and lung weights (\%)

Percentage of tracheal and lung weight of skin obtained from rakea and lung weights divided by empty body weight multiplied by $100 \%$

f. Heart weight predentation (\%)

The percentage of liver weight is obtained from the weight of the liver divided by the empty body weight multiplied by $100 \%$

g. Percent weight of heart $(\%)$ 
Percentage of heart weight obtained from heart weight divided by empty body weight multiplied by $100 \%$

h. Prediction of blood weight (\%)

Percentage of blood weight obtained from blood weight divided by empty body weight multiplied by $100 \%$

i. Percentage of gastrointestinal weight (\%)

Percentage of gastrointestinal weights obtained from the weight of the gastrointestinal tract divided by the empty body weight multiplied by $100 \%$

\section{Results and Discussion}

To see the results of research on the percentage of head, legs, skin, tail, trachea and lung, liver, heart, blood and gastrointestinal tracts of local sheep, recapitulation can be done in Table 25 .

Table 25. Recapitulation of research results

\begin{tabular}{|c|c|c|c|c|c|c|}
\hline \multirow{2}{*}{ No. } & \multirow{2}{*}{ Parameter } & \multicolumn{4}{|c|}{ Treatment } & \multirow[t]{2}{*}{ Average } \\
\hline & & $\mathrm{P}_{0}$ & $\mathrm{P}_{1}$ & $\mathrm{P}_{2}$ & $\mathrm{P}_{3}$ & \\
\hline 1. & Head & $8.43^{\text {tn }}$ & $8.22^{\text {tn }}$ & $8.28^{\text {tn }}$ & $8.38^{\operatorname{tn}}$ & 8.33 \\
\hline 2. & Legs & $3.86^{\mathrm{tn}}$ & $3.75^{\mathrm{tn}}$ & $3.56^{\mathrm{tn}}$ & $3.73^{\mathrm{tn}}$ & 3.73 \\
\hline 3. & Skin & $14.79^{\operatorname{tn}}$ & $14.26^{\mathrm{tn}}$ & $14.20^{\operatorname{tn}}$ & $15.00^{\operatorname{tn}}$ & 14.56 \\
\hline 4. & Tails & $0.24^{\mathrm{tn}}$ & $0.25^{\mathrm{tn}}$ & $0.24^{\mathrm{tn}}$ & $0.24^{\mathrm{tn}}$ & 0.24 \\
\hline 5. & Trachea and Lungs & $1.75^{\mathrm{tn}}$ & $1.69^{\mathrm{tn}}$ & $1.70^{\mathrm{tn}}$ & $1.72^{\mathrm{tn}}$ & 1.71 \\
\hline 6. & Heart & $1.63^{\mathrm{tn}}$ & $1.58^{\mathrm{tn}}$ & $1.61^{\mathrm{tn}}$ & $1.62^{\mathrm{tn}}$ & 1.61 \\
\hline 7. & Heart & $0.63^{\mathrm{tn}}$ & $0.58^{\mathrm{tn}}$ & $0.61^{\mathrm{tn}}$ & $0.61^{\mathrm{tn}}$ & 0.61 \\
\hline 8. & Blood & $3.54^{\mathrm{tn}}$ & $3.46^{\mathrm{tn}}$ & $3.50^{\operatorname{tn}}$ & $3.54^{\mathrm{tn}}$ & 3.15 \\
\hline 9. & Digestive Tract & $13.07^{\mathrm{tn}}$ & $13.35^{\mathrm{tn}}$ & $12.79^{\operatorname{tn}}$ & $13.73^{\text {tn }}$ & 13.23 \\
\hline
\end{tabular}

Information. $\mathrm{tn}=$ no real difference

Based on the results of the above recapitulation, it was found that the substitution of forage with the waste of white fermented oyster mushroom media planting media did not give a significant effect on weight percentage of head, leg, skin, tail, trachea, lung, heart, heart, blood and channel digestion in local sheep.

\section{Conclusions}

Wastewater planting white fermented oyster mushroom can substitute forage as local lamb feed, but it can not increase the percentage of non-carcass component worth eating.

\section{References :}

[1] Setiadi, B. 2003. Alternatif konsep pembibitan dan Pengembangan Usaha Ternak Kambing. Jurnal Peternakan

[2] Haryanto, B. 1992. Pakan domba dan kambing. Proceeding Sarasehan Usaha

[3] Tarmidi, A.R., H. Denie., U.H. Tanurwiria., and M. Dwi. 2007. Pemberian Berbagai Level Limbah Media Jamur Tiram Putih (Pleurotus ostreatus) dalam Ransum yang Berbasis Pucuk Tebu Terhadap Performa Domba Garut. Fakultas Peternakan Universitas Padjajaran. Jatinangor

[4] Winarno, F.G. 1980. Bahan Pangan Terfermentasi. Pusat Penelitian dan Pengembangan Teknologi Pangan. Institut Pertanian Bogor. Bogor

[5] Soeparno. 2005. Ilmu dan Teknologi Daging. Cetakan Ke-4. Gadjah Mada University Press, Yogyakarta. 
[6] Ternak Domba dan Kambing Menyongsong Era PJPT II : 26-32. Balai Penelitian Ternak Ciawi, Bogor. Jendral Peternakan Departemen Pertanian. Jakarta 